\title{
Adsorption of Heavy Metals by Brewery Biomass
}

\author{
Tae-Young Kim, Sun-Kyu Park, Sung-Yong Cho, Hwan-Beom Kim*, Yong Kang**, \\ Sang-Done Kim**** and Seung-Jai Kim $* * * *,+$ \\ Department of Environmental Engineering, ****Envrionmental Research Institute, Chonnam National University, \\ 300 Yongbong-dong, Buk-ku, Gwang-ju 500-757, Korea \\ *Jeollanam-Do Institute of Health and Environment, Nongseong 2-dong, Seo-ku, Gwang-ju 502-202, Korea \\ **Department of Chemical Engineering, Chungnam National University, Daejeon 305-764, Korea \\ ****Department of Chemical Engineering, Korea Advanced Institute of Science and Technology, Daejeon 305-701, Korea \\ (Received 21 April $2004 \cdot$ accepted 16 November 2004)
}

\begin{abstract}
In this work, biosorption of lead, copper and cadmium by waste brewery yeast has been studied. The adsorption capacity for lead, copper and cadmium on the biomass increased with the increasing temperature and the maximum uptakes were $0.465 \mathrm{mmolPb} / \mathrm{g}(96.4 \mathrm{mg} / \mathrm{g}), 0.769 \mathrm{mmolCu} / \mathrm{g}(48.9 \mathrm{mg} / \mathrm{g})$ and $0.127 \mathrm{mmolCd} / \mathrm{g}(14.3 \mathrm{mg} / \mathrm{g})$ at $308 \mathrm{~K}$. The Langmuir isotherm, favorable type, and the pseudo second-order kinetic model represent our experimental data very well. The heat of biosorption was evaluated from the Langmuir isotherm equation, and the biosorption of lead, copper and cadmium was endothermic reaction.
\end{abstract}

Key words: Biosorption, Brewery Yeast, Heavy Metal, Adsorption Capacity

\section{INTRODUCTION}

Toxic heavy metals are released into the environment from a number of industries such as mining, plating, dyeing, automobile manufacturing and metal processing. The presence of heavy metals in the environment has led to a number of environmental problems. In order to meet the water quality standards for most of countries, the concentration of heavy metals in wastewater must be controlled. Conventional physico-chemical treatment methods for removing heavy metals include precipitation, filtration, oxidation-reduction, ion exchange and membrane separation. However, when metals are dissolved in huge volumes at relatively low concentration, these methods become generally ineffective or expensive [Aderhold et al., 1996; Blanco et al., 1999; Lee and Suh, 2000; Eccles, 1995]. Therefore, there is a need for the development of a low cost process to remove heavy metals economically.

Biosorption is a process that utilizes biological materials as adsorbents, and this method has been studied by several researchers as an alternative technique to conventional methods for heavy metal removal from wastewater [Jeon et al., 2001; Sa and Kutsal, 2001; Volesky, 2001; Yu et al., 1999].

The binding mechanisms of heavy metals by biosorption could be explained by the physical and chemical interactions between cell wall ligands and adsorbates by ion exchange, complexation, coordination and microprecipitation. The diffusion of the metal from the bulk solution to active sites of biosorbents occurs predominantly by passive transport mechanisms [Veglio and Beolchini, 1997] and various functional groups such as carboxyl, hydroxyl, amino and phosphate existing on the cell wall of biosorbents can bind the heavy metals [Avery and Tobin, 1993]. Living or dead biomass can be used to remove metals, but maintaining a living biomass during metal

To whom correspondence should be addressed.

E-mail: sjkim@chonnam.ac.kr biosorption is difficult because it requires a continuous supply of nutrients and toxicity of metal for microorganism might take place. On the other hand, the use of dead biomass can avoid these problems and the used cells can be easily regenerated [Sudha and Abraham, 2001; Yan and Viraraghavan, 2001].

A variety of biomaterials such as bacteria, yeast, algae and fungi have been successfully used as biosorbents for the removal of heavy metals [Kapoor and Viraraghavan, 1995; Volesky, 1994]. Bailey et al. [1999] defined a low cost sorbent as one that is abundant in nature, or is a by-product or waste material from industries such as breweries and dairy products. The yeast has been studied by many investigators as a biosorbent since it can be obtained without additional cost or easily cultivated in substantial amounts using simple fermentation techniques and inexpensive growth media [Aksu and Dönmez, 2003; Avery and Tobin, 1992; Jianlon, 2002; Marques et al., 1999].

In this work, the waste brewery yeast was obtained from a fermentation process of a brewery plant, and the biosorption of lead, copper and cadmium was studied in a batch reactor with respect to the $\mathrm{pH}$, initial metal concentration and temperature. Biosorption equilibria and kinetics over the temperature range of 288-308 K were investigated and the biosorption heat was evaluated.

\section{MATERIALS AND METHODS}

\section{Preparation of Biosorbent}

The biomass, collected from a brewery plant, was washed several times with distilled water, and then dried in a vacuum drying oven at $80^{\circ} \mathrm{C}$ for $48 \mathrm{~h}$. The dried biomass was grounded with a mortar and pestle. The particles were separated by using a US standard testing sieve (No. 100 No. 200) and stored in a sealed bottle with a silica gel to prevent readsorption of moisture.

\section{Biosorption Equilibrium}

Heavy metal solutions were prepared by dissolving metal nitrates, 
$\left(\mathrm{Pb}\left(\mathrm{NO}_{3}\right)_{2}, \mathrm{Cu}\left(\mathrm{NO}_{3}\right)_{2} \cdot 3 \mathrm{H}_{2} \mathrm{O}, \mathrm{Cd}\left(\mathrm{NO}_{3}\right)_{2} \cdot 4 \mathrm{H}_{2} \mathrm{O}\right)$, in distilled water. The mixture containing $0.1 \mathrm{~g}$ of biosorbent and $100 \mathrm{ml}$ of metal nitrate solution was agitated on a shaking incubator at $150 \mathrm{rpm}$ for $24 \mathrm{~h}$ in $300 \mathrm{~mL}$ an Erlenmayer flask. The $\mathrm{pH}$ of solution (initial metal concentration of $200 \mathrm{mg} / \mathrm{L}$ ) was adjusted between 2.5 and 6.0 with $1 \mathrm{~N}$ $\mathrm{HNO}_{3}$ and $1 \mathrm{~N} \mathrm{NaOH}$, and the temperature was adjusted between $288 \mathrm{~K}$ and $308 \mathrm{~K}$. The heavy metal concentration was varied over the range of $0.1-5.0 \mathrm{mmol} / \mathrm{L}$. After equilibrium experiments, the biosorbent was separated from the solution by centrifugation for $10 \mathrm{~min}$ at $10,000 \mathrm{rpm}$ and then the residual metal concentration in the solution was analyzed by ICP (Leeman 010-2106). The amounts of lead, copper and cadmium adsorbed onto the biomass at equilibrium were calculated from the following mass balance equation:

$$
\mathrm{q}=\left(\mathrm{C}_{i}-\mathrm{C}\right) \frac{\mathrm{V}}{\mathrm{W}}
$$

Here $\mathrm{q}$ is the equilibrium amount adsorbed on the biomass (mol/ $\mathrm{kg}), \mathrm{C}_{i}$ is the initial concentration of bulk fluid $\left(\mathrm{mol} / \mathrm{m}^{3}\right), \mathrm{C}$ is the equilibrium concentration of the solution $\left(\mathrm{mol} / \mathrm{m}^{3}\right), \mathrm{V}$ is the volume of solution $\left(\mathrm{m}^{3}\right)$, and $\mathrm{W}$ is the weight of biomass $(\mathrm{kg})$.

\section{Biosorption Kinetics}

Biosorbent, $0.2 \mathrm{~g}$, was suspended in $200 \mathrm{ml}$ of metal nitrate solution and initial metal concentration was varied over the range 10$200 \mathrm{mg} / \mathrm{L}$. For kinetic experiments, four different biosorbent concentrations varying between $0.5-4.0 \mathrm{~g} / \mathrm{L}$ at an initial heavy metal concentration of $100 \mathrm{mg} / \mathrm{L}$ were used. The $\mathrm{pH}$ and agitation speed of this experiment were the same as those for equilibrium study. Samples were withdrawn at pre-determined time intervals, centrifuged and then analyzed for residual metal concentration.

\section{RESULTS AND DISCUSSION}

\section{Effect of $\mathbf{p H}$}

The biosorption capacities of lead, copper and cadmium on vari-

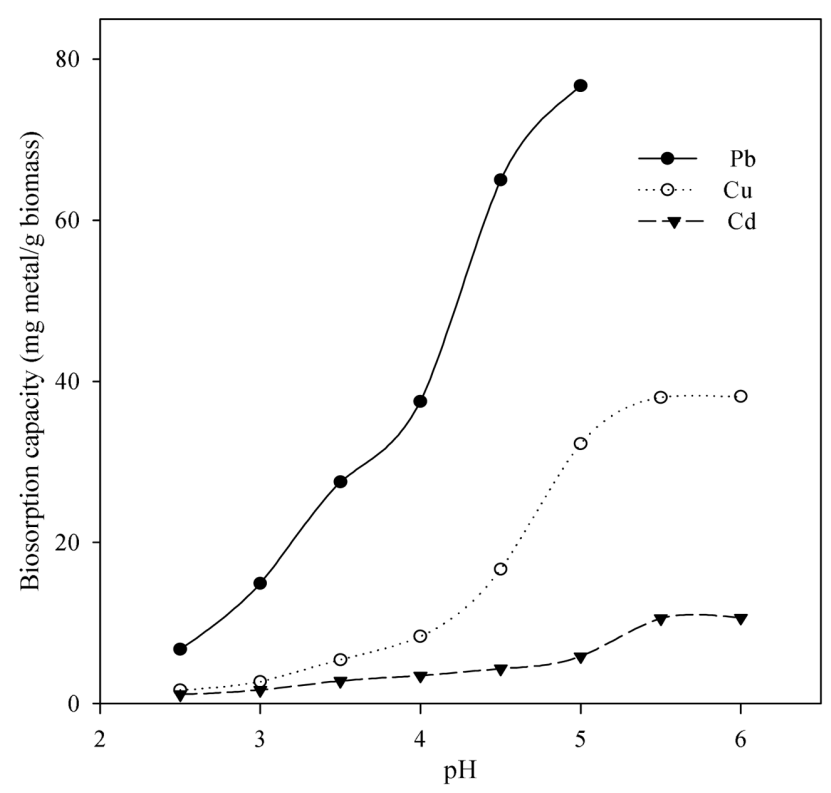

Fig. 1. Effect of initial pH on the biosorption capacity (Co: $200 \mathrm{mg}$ / $\mathrm{L}$, biomass conc.: $1 \mathrm{~g} / \mathrm{L}, 150 \mathrm{rpm}, 25^{\circ} \mathrm{C}$ ). ous $\mathrm{pH}$ values are shown in Fig. 1. The experiments were not conducted above $\mathrm{pH} 6.0$ (5.0 for $\mathrm{Pb}$ ) to avoid possible hydroxide precipitation. The biosorption capacity increased with increasing $\mathrm{pH}$ and the effect of $\mathrm{pH}$ was in the order of $\mathrm{Pb}>\mathrm{Cu}>\mathrm{Cd}$. The effect of $\mathrm{pH}$ on the biosorption capacity can be interpreted by the competition of the hydronium ions $\left[\mathrm{H}_{3} \mathrm{O}^{+}\right]$and metal ions for binding sites. At low $\mathrm{pH}$ values, the ligands on the cell are closely associated with the hydronium ions, but when the $\mathrm{pH}$ is increased, the hydronium ions are gradually dissociated and the positively charged metal ions are associated with the free binding sites. Similar findings were reported by other researchers [Benguella and Benaissa, 2002; Esposito et al., 2002; Yang and Volesky, 1999].

\section{Biosorption Equilibrium}

Adsorption isotherms are very important for the design of an adsorption-based process design. In this study, the Langmuir isotherm model was used to correlate our experimental equilibrium data. The Langmuir equations have two parameters in Eq. (2).

$$
\mathrm{q}=\frac{\mathrm{q}_{m} \mathrm{bc}_{e}}{1+\mathrm{bc}_{e}}
$$

To find the parameters for adsorption isotherm equation, the linear least squares method and the pattern search algorithm (NMEAD) were used. The value of the mean percentage error, obtained from Eq. (3), has been used as a test criterion for the fit of the correlation.

$$
\operatorname{Error}(\%)=\frac{100}{\mathrm{~N}} \sum_{k=1}^{N}\left[\frac{\left|\mathbf{q}_{\text {exp }}-\mathrm{q}_{c a l}\right|}{\mathbf{q}_{\text {exp }}}\right]
$$

The parameters and the average percent differences between the measured and calculated values are given in Table 1 . The equilibrium adsorption data for lead, copper and cadmium at four different temperature are shown in Figs. 2-4 along with the Langmuir isotherm equation. As can be seen in this figures, the equilibrium isotherm was favorable type and the Langmuir equation represents our experimental data very well. The applicability of the Langmuir isotherm indicates good monolayer coverage of the metal ions on the surface of the biomass. The adsorption capacity for lead, copper and cadmium increased with increasing temperature and the maximum uptakes were $0.465 \mathrm{mmolPb} / \mathrm{g}(96.4 \mathrm{mg} / \mathrm{g}), 0.769 \mathrm{mmolCu} /$

\begin{tabular}{|c|c|c|c|c|c|}
\hline \multirow{2}{*}{$\begin{array}{l}\text { Heavy } \\
\text { metal }\end{array}$} & \multirow{2}{*}{ Parameters } & \multicolumn{4}{|c|}{ Temperature } \\
\hline & & $288 \mathrm{~K}$ & $298 \mathrm{~K}$ & $303 \mathrm{~K}$ & $308 \mathrm{~K}$ \\
\hline \multirow[t]{3}{*}{ Lead } & $\mathrm{q}_{m}$ & 0.358 & 0.422 & 0.442 & 0.465 \\
\hline & $\mathrm{b}$ & 4.27 & 9.87 & 11.31 & 12.40 \\
\hline & error $(\%)$ & 6.36 & 7.99 & 6.70 & 1.10 \\
\hline \multirow[t]{3}{*}{ Copper } & $\mathrm{q}_{\mathrm{m}}$ & 0.608 & 0.707 & 0.754 & 0.769 \\
\hline & $\mathrm{b}$ & 1.76 & 3.21 & 3.55 & 4.16 \\
\hline & error $(\%)$ & 6.18 & 3.95 & 6.73 & 8.03 \\
\hline \multirow[t]{3}{*}{ Cadmium } & $\mathrm{q}_{m}$ & 0.104 & 0.107 & 0.125 & 0.127 \\
\hline & $\mathrm{b}$ & 1.74 & 3.15 & 5.62 & 6.61 \\
\hline & error (\%) & 6.45 & 6.50 & 4.84 & 6.78 \\
\hline
\end{tabular}

Table 1. Adsorption equilibrium parameters of lead, cadmium and copper 


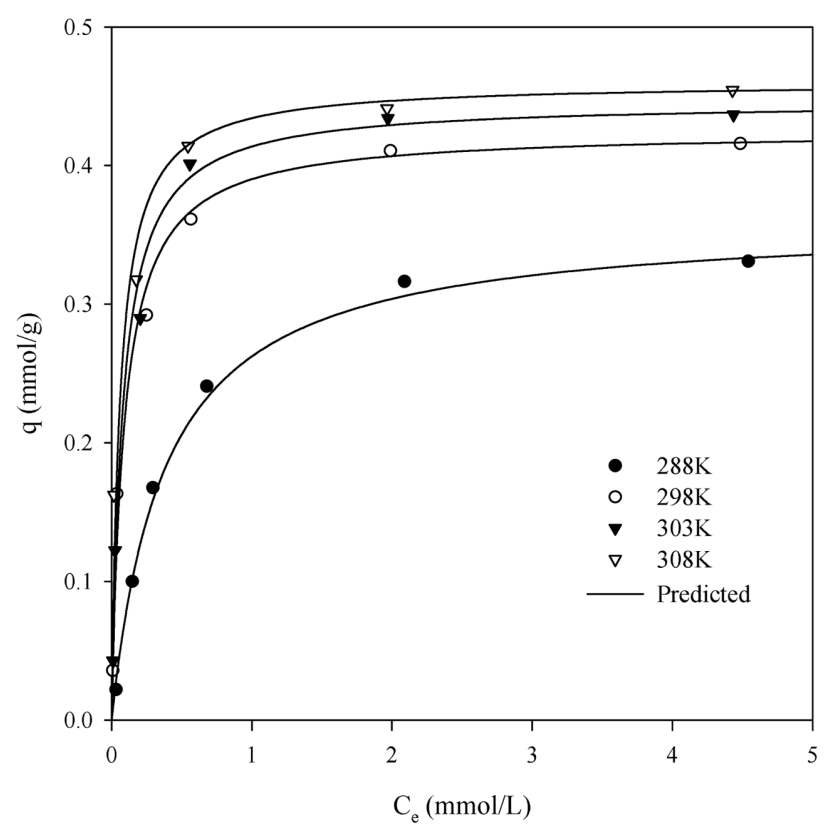

Fig. 2. Adsorption equilibrium isotherm of lead (pH 5.0).

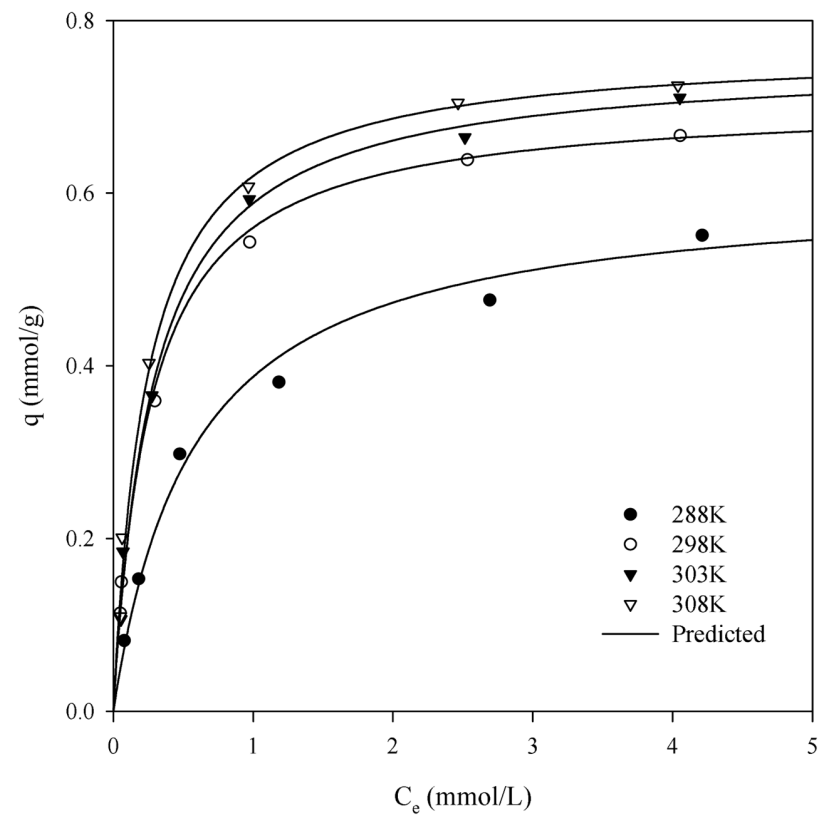

Fig. 3. Adsorption equilibrium isotherm of copper (pH 5.5).

$\mathrm{g}(48.9 \mathrm{mg} / \mathrm{g})$ and $0.127 \mathrm{mmolCd} / \mathrm{g}(14.3 \mathrm{mg} / \mathrm{g})$ at $308 \mathrm{~K}$.

\section{Heat of Adsorption}

The heat of adsorption can be calculated by using the Langmuir parameter, $b$, and this parameter can be expressed as a function of temperature by the following Arrhenius type relationship:

$$
\mathrm{b}=\mathrm{b}_{0} \exp \left[-\frac{\Delta \mathrm{H}}{\mathrm{RT}}\right]
$$

where $\mathrm{b}_{0}$ is a constant, $\Delta \mathrm{H}(\mathrm{kcal} / \mathrm{mol})$ is the heat of adsorption, $\mathrm{R}$ is a universal gas constant and $\mathrm{T}$ is the absolute temperature $(\mathrm{K})$. If $\mathrm{b}$ values are known for various temperatures, the heat of adsorption can be calculated from the plots of $\log \mathrm{b}$ versus $1 / \mathrm{T}$ [Özer and Özer, 2003].

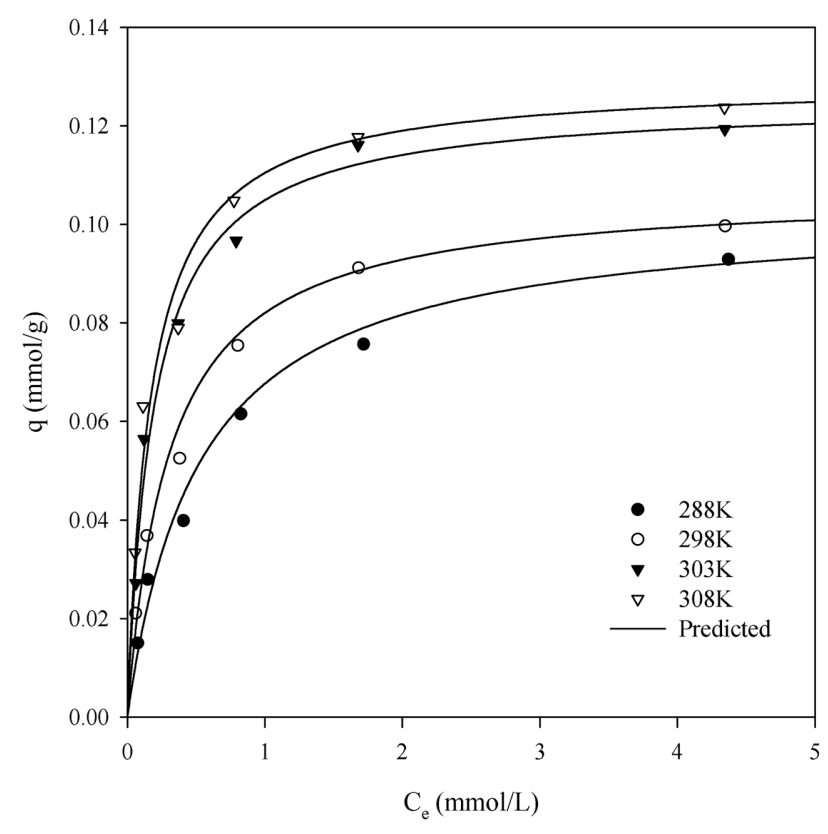

Fig. 4. Adsorption equilibrium isotherm of cadmium (pH 5.5).

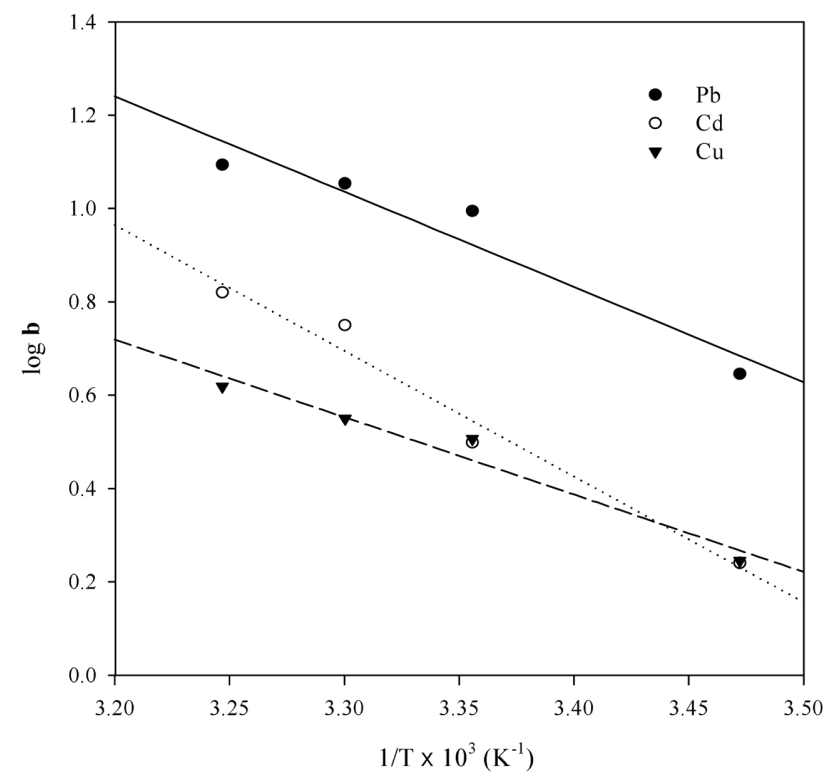

Fig. 5. Variation of the Langmuir constant (b) with temperature.

Table 2. The values of biosorption heat for lead, cadmium and copper and regression coefficients

\begin{tabular}{lcc}
\hline \hline Heavy metal & Biosorption heat $(\mathrm{kcal} / \mathrm{mol})$ & $\mathrm{R}^{2}$ \\
\hline Lead & 4.06 & 0.92 \\
Copper & 3.30 & 0.96 \\
Cadmium & 5.35 & 0.97 \\
\hline
\end{tabular}

The variation of $\mathrm{b}$ with temperature is shown in Fig. 5, and the biosorption heats and regression coefficients obtained are summarized in Table 2. As shown in Table 2, the biosorption heats for lead, copper and cadmium are 4.06, 3.30 and $5.35 \mathrm{kcal} \cdot \mathrm{mol}^{-1}$, respec- 
tively. The values of biosorption heat for the three heavy metals show that the reaction is endothermic. Nakajima et al. [1982] also reported that the biosorption of uranium by polyacrylamide-immobilized S. viridochromogenes and C. regularis was an endothermic reaction and similar results were reported for biosorption of cadmium and lead by spent grain [Low et al., 2000].

In general, the heat of physical adsorption is no more than $1 \mathrm{kcal} \cdot$ $\mathrm{mol}^{-1}$, and that of chemical adsorption is $20-50 \mathrm{kcal} \cdot \mathrm{mol}^{-1}$ [Smith, 1981]. Since the heats of adsorption for the heavy metals of our study are 3.3-5.4 kcal $\cdot \mathrm{mol}^{-1}$, we believe that both physical and chemical adsorptions are involved in the biosorption. Sağ [1993] also reported that the adsorption heats for the biosorption of $\mathrm{Pb}$ (II) ions on Z rami-

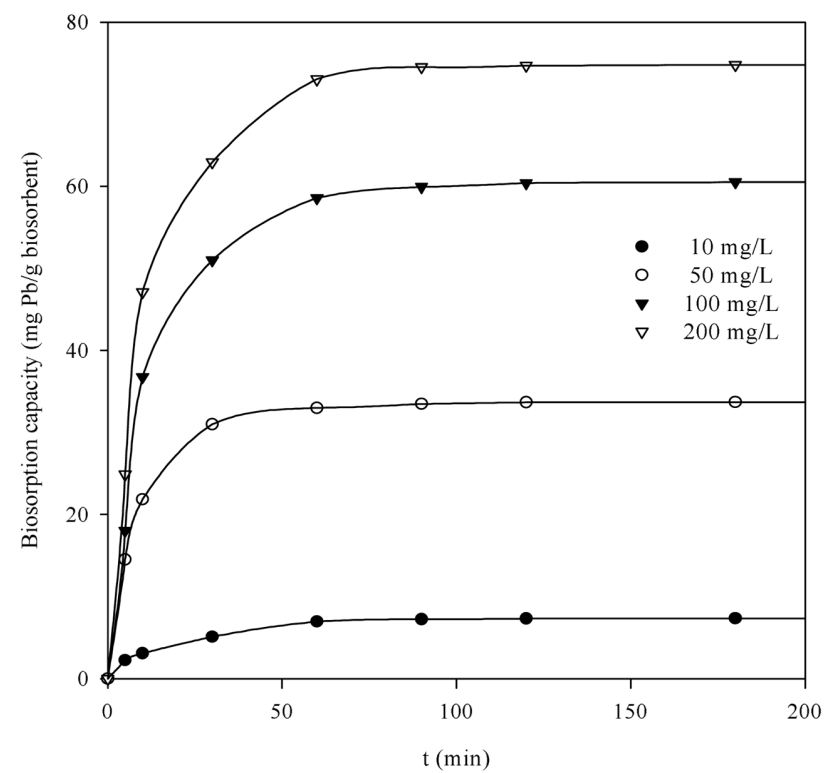

Fig. 6. Biosorption capacity of lead for different mental concentration (pH 5.0).

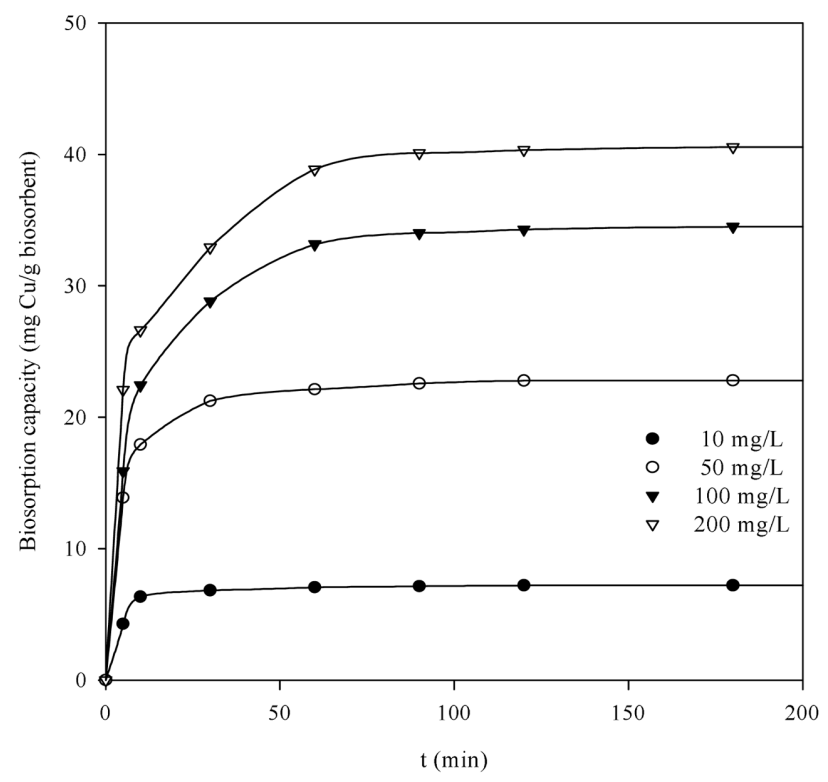

Fig. 7. Biosorption capacity of copper for different metal concentration (pH 5.5). gera and Ni(II) ions on $R$. arrhizus have values between physical adsorption and chemical adsorption.

\section{Kinetic Studies}

The effects of initial metal concentration $(10,50,100,200 \mathrm{mg} /$ $\mathrm{L})$ and biosorbent concentration $(0.5,1.0,2.0,4.0 \mathrm{~g} / \mathrm{L})$ on the adsorption kinetics of heavy metals are studied. Figs. 6-8 show the amounts of the metal adsorbed onto biosorbent, biosorption capacity, with reaction time for different metal concentration. The adsorption capacities of lead and copper increased rapidly in the beginning of the reaction and reached equilibrium in about $60 \mathrm{~min}$, but that of cadmium reached at equilibrium in about $120 \mathrm{~min}$. The figures also show that the adsorption capacities of lead, copper and cadmium

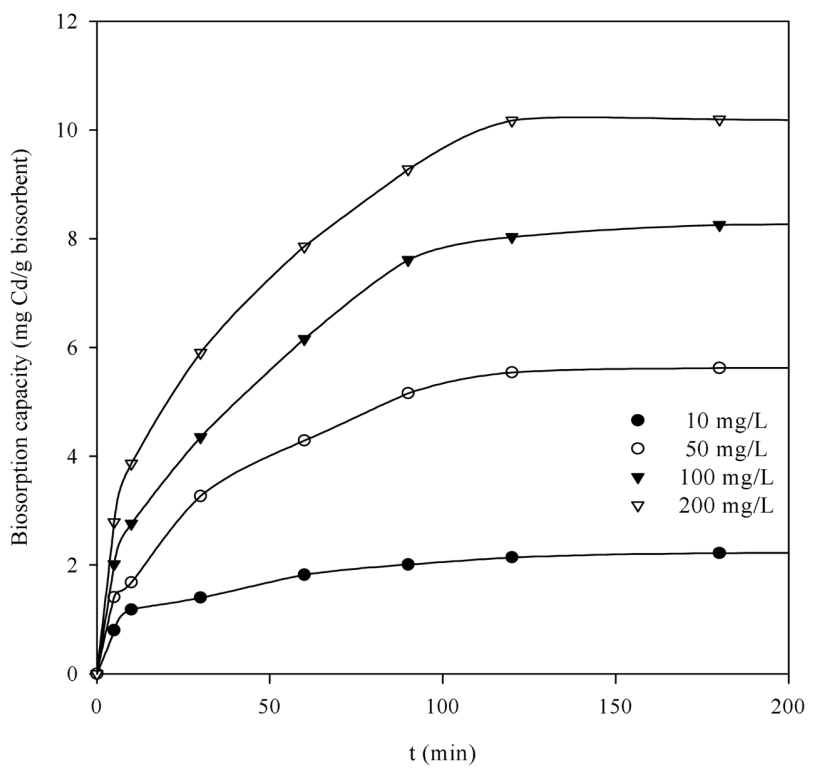

Fig. 8. Biosorption capacity of cadmium for different metal concentration (pH 5.5).

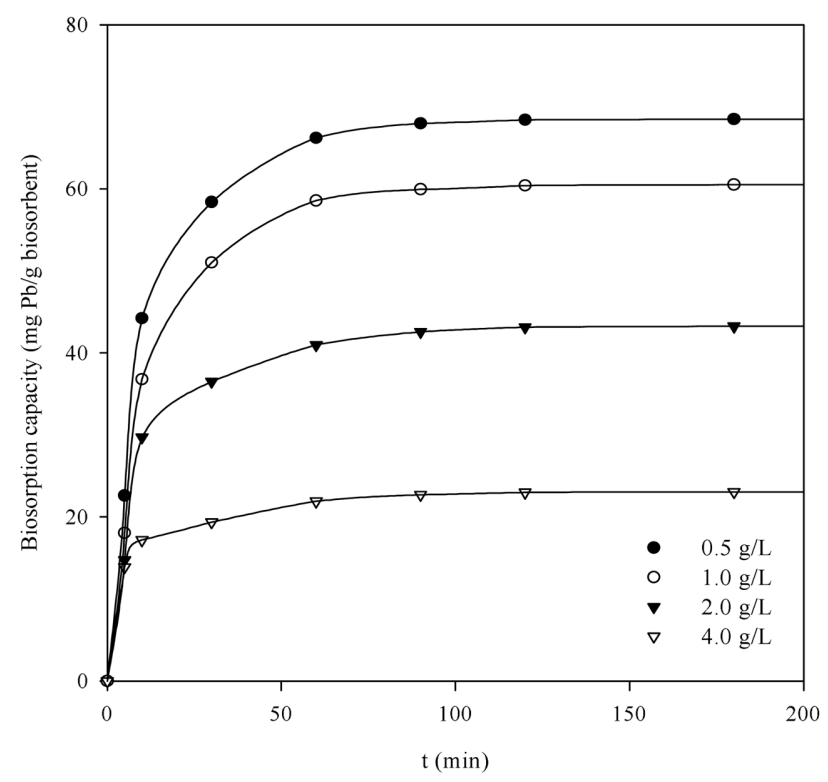

Fig. 9. Biosorption capacity of lead for different biosorbent concentration (pH 5.0). 


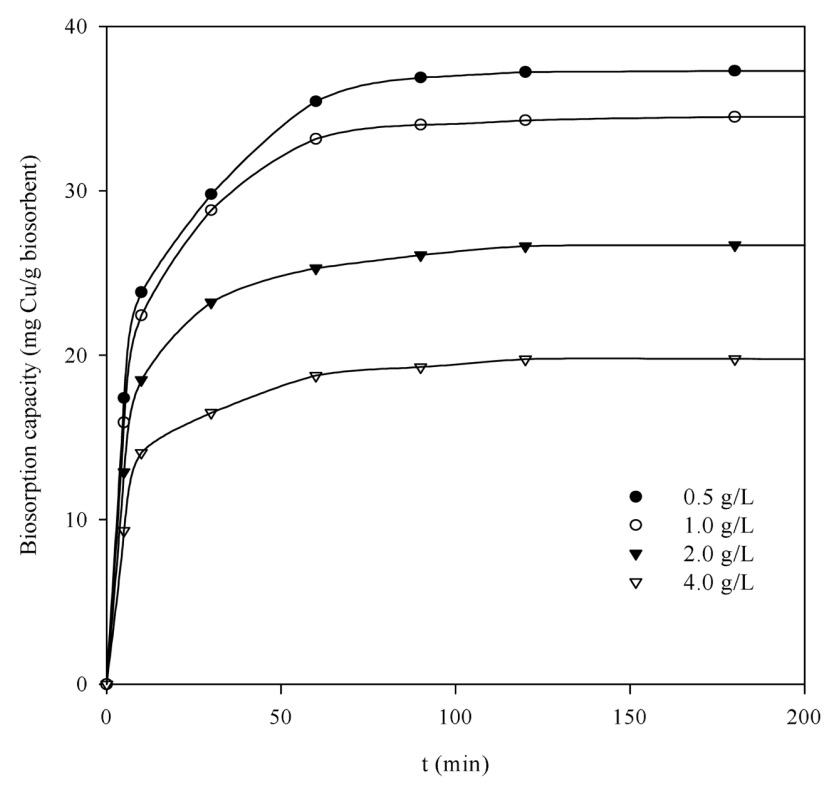

Fig. 10. Biosorption capacity of copper for different biosorbent concentration (pH 5.5).

increased with increasing initial metal concentration.

Figs. 9-11 show the variation of biosorption capacity for different biosorbent concentration. As shown in Figs. 9-10, the biosorption capacity profiles of lead and copper are very similar and the capacities increase rapidly in the beginning of the reaction. The biosorption capacities of lead and copper for higher biomass concentrations ( 2 and $4 \mathrm{~g} / \mathrm{L}$ ) reach equilibrium within $10 \mathrm{~min}$, but more than $60 \mathrm{~min}$ was required to reach equilibrium capacities for lower biomass concentrations $(0.5$ and $1 \mathrm{~g} / \mathrm{L})$. Although the biosorption capacity profiles of lead and copper are very similar, the capacity of lead was substantially higher than that for copper. As for cadmium, Fig. 11, the profile as well as biosorption capacity are very different--longer time to reach equilibrium and much lower biosorption capacity.

In order to analyze the biosorption kinetics of lead, copper and cadmium, the pseudo first-order and second-order kinetic models

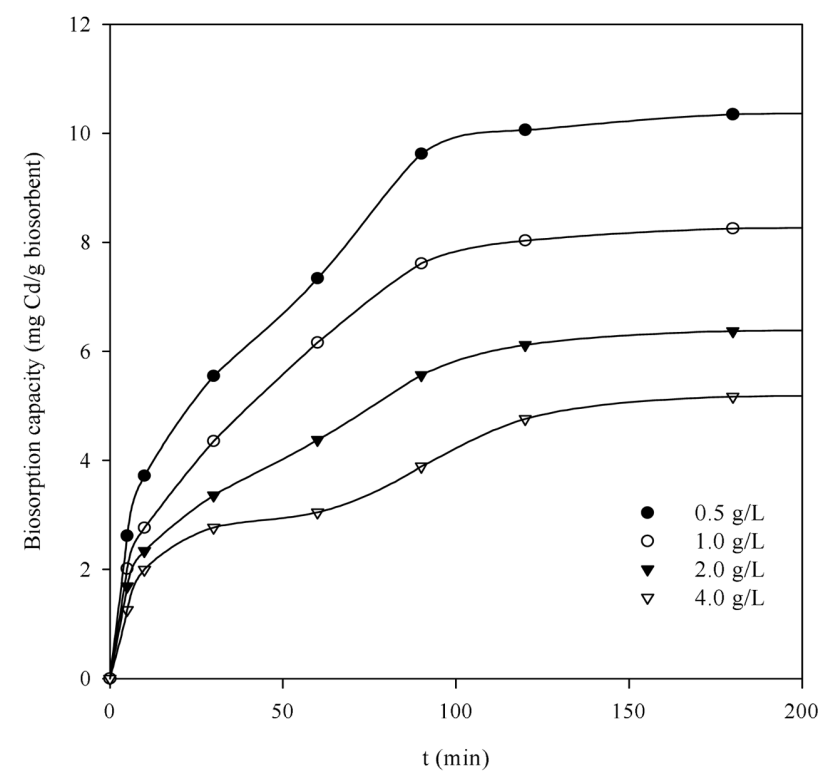

Fig. 11. Biosorption capacity of cadmium for different biosorbent concentration (pH 5.5).

were applied to the experimental data.

The pseudo first-order rate expression of Lagergren [1898] can be expressed as:

$$
\log \left(\mathrm{q}_{e q}-\mathrm{q}_{t}\right)=\log \mathrm{q}_{e q}-\frac{\mathrm{k}_{1, a d}}{2.303} \mathrm{t}
$$

where, $\mathrm{q}_{e q}$ and $\mathrm{q}_{t}$ are the amounts ( $\mathrm{mg} / \mathrm{g}$ ) of adsorbed metal on the biosorbent at equilibrium and at time $\mathrm{t}$, respectively. $\mathrm{k}_{1, a d}$ is the rate constant $(\mathrm{L} / \mathrm{min})$. If Eq. (5) is applicable, the adsorption rate is the pseudo first-order reaction, and the rate constant $\mathrm{k}_{1, \text { ad }}$ can be obtained from the slope of the plot of $\log \left(\mathrm{q}_{e q}-\mathrm{q}_{t}\right)$ against $\mathrm{t}$.

The pseudo second-order rate equation [Ho and Mckay, 1998] can be expressed as:

$$
\frac{\mathrm{t}}{\mathrm{q}_{t}}=\frac{1}{\mathrm{k}_{2, a d} \mathrm{q}_{e q}^{2}}+\frac{1}{\mathrm{q}_{e q}} \mathrm{t}
$$

\begin{tabular}{|c|c|c|c|c|c|c|c|c|}
\hline \multirow{2}{*}{$\begin{array}{l}\text { Heavy } \\
\text { metal }\end{array}$} & \multirow{2}{*}{$\begin{array}{c}\text { Initial } \\
\text { concentration }\end{array}$} & \multicolumn{3}{|c|}{ First-order kinetic model } & \multicolumn{3}{|c|}{ Second-order kinetic model } & \multirow{2}{*}{$\begin{array}{c}\mathrm{q}_{\text {eq,exp }} \\
(\mathrm{mg} / \mathrm{g})\end{array}$} \\
\hline & & $\mathrm{K}_{1, a d} \times 10^{-2}\left(\mathrm{~min}^{-1}\right)$ & $\mathrm{q}_{e q}(\mathrm{mg} / \mathrm{g})$ & $\mathrm{R}^{2}$ & $\mathrm{~K}_{2, a d} \times 10^{-2}\left(\mathrm{~g} \mathrm{mg}^{-1} \min ^{-1}\right)$ & $\mathrm{q}_{e q}(\mathrm{mg} / \mathrm{g})$ & $\mathrm{R}^{2}$ & \\
\hline \multirow[t]{4}{*}{ Lead } & $10 \mathrm{mg} / \mathrm{L}$ & 3.96 & 6.53 & 0.974 & 0.93 & 8.04 & 0.995 & 7.44 \\
\hline & $50 \mathrm{mg} / \mathrm{L}$ & 4.77 & 17.96 & 0.956 & 0.57 & 34.97 & 0.999 & 33.82 \\
\hline & $100 \mathrm{mg} / \mathrm{L}$ & 4.93 & 44.05 & 0.983 & 0.19 & 64.10 & 0.998 & 60.54 \\
\hline & $200 \mathrm{mg} / \mathrm{L}$ & 5.87 & 61.04 & 0.988 & 0.17 & 78.74 & 0.998 & 74.86 \\
\hline \multirow[t]{4}{*}{ Copper } & $10 \mathrm{mg} / \mathrm{L}$ & 3.75 & 1.83 & 0.859 & 5.81 & 7.32 & 0.999 & 7.22 \\
\hline & $50 \mathrm{mg} / \mathrm{L}$ & 3.94 & 7.73 & 0.963 & 1.45 & 23.26 & 0.998 & 22.83 \\
\hline & $100 \mathrm{mg} / \mathrm{L}$ & 4.24 & 20.12 & 0.991 & 0.53 & 35.71 & 0.999 & 34.52 \\
\hline & $200 \mathrm{mg} / \mathrm{L}$ & 4.33 & 23.58 & 0.993 & 0.42 & 42.02 & 0.997 & 40.58 \\
\hline \multirow[t]{4}{*}{ Cadmium } & $10 \mathrm{mg} / \mathrm{L}$ & 1.66 & 1.55 & 0.984 & 2.94 & 2.37 & 0.995 & 2.37 \\
\hline & $50 \mathrm{mg} / \mathrm{L}$ & 2.10 & 5.11 & 0.991 & 0.61 & 6.48 & 0.994 & 5.90 \\
\hline & $100 \mathrm{mg} / \mathrm{L}$ & 2.28 & 7.63 & 0.978 & 0.41 & 9.51 & 0.991 & 8.47 \\
\hline & $200 \mathrm{mg} / \mathrm{L}$ & 2.33 & 8.47 & 0.982 & 0.40 & 11.49 & 0.993 & 10.25 \\
\hline
\end{tabular}

Table 3. Comparison of the first-order and second-order rate constants for different initial metal concentration 
where $\mathrm{k}_{2, a d}$ is the rate constant of pseudo second-order kinetic model (g/mg-min). If Eq. (6) is applicable, the plot of $t / q_{t}$ against $t$ should give a linear relationship, and $\mathrm{q}_{e q}$ and $\mathrm{k}_{2, a d}$ can be determined from the slope and intercept of the plot.

The values of model parameters $\mathrm{k}_{1, a d}, \mathrm{k}_{2, a d}, \mathrm{q}_{e q}$ and correlation coefficients $\left(\mathrm{R}^{2}\right)$ are obtained and presented in Tables 3 and 4 . As

Table 4. Comparison of the first-order and second-order rate constants for different biosorbent concentration

\begin{tabular}{|c|c|c|c|c|c|c|c|c|}
\hline \multirow{2}{*}{$\begin{array}{l}\text { Heavy } \\
\text { metal }\end{array}$} & \multirow{2}{*}{$\begin{array}{c}\text { Initial } \\
\text { concentration }\end{array}$} & \multicolumn{3}{|c|}{ First-order kinetic model } & \multicolumn{3}{|c|}{ Second-order kinetic model } & \multirow{2}{*}{$\begin{array}{c}\mathrm{q}_{\text {eq,exp }} \\
(\mathrm{mg} / \mathrm{g})\end{array}$} \\
\hline & & $\mathrm{K}_{1, a d} \times 10^{-2}\left(\mathrm{~min}^{-1}\right)$ & $\mathrm{q}_{e q}(\mathrm{mg} / \mathrm{g})$ & $\mathrm{R}^{2}$ & $\mathrm{~K}_{2, a d} \times 10^{-2}\left(\mathrm{~g} \mathrm{mg}^{-1} \mathrm{~min}^{-1}\right)$ & $\mathrm{q}_{e q}(\mathrm{mg} / \mathrm{g})$ & $\mathrm{R}^{2}$ & \\
\hline \multirow[t]{4}{*}{ Lead } & $0.5 \mathrm{~g} / \mathrm{L}$ & 5.09 & 48.38 & 0.992 & 0.19 & 71.94 & 0.994 & 68.50 \\
\hline & $1.0 \mathrm{~g} / \mathrm{L}$ & 4.93 & 44.05 & 0.991 & 0.19 & 64.10 & 0.992 & 60.54 \\
\hline & $2.0 \mathrm{~g} / \mathrm{L}$ & 3.98 & 24.87 & 0.980 & 0.68 & 43.29 & 0.995 & 43.30 \\
\hline & $4.0 \mathrm{~g} / \mathrm{L}$ & 3.52 & 9.94 & 0.984 & 0.94 & 23.70 & 0.998 & 23.11 \\
\hline \multirow[t]{4}{*}{ Copper } & $0.5 \mathrm{~g} / \mathrm{L}$ & 4.31 & 24.07 & 0.987 & 0.39 & 38.91 & 0.994 & 37.36 \\
\hline & $1.0 \mathrm{~g} / \mathrm{L}$ & 4.24 & 20.12 & 0.983 & 0.47 & 35.84 & 0.999 & 34.52 \\
\hline & $2.0 \mathrm{~g} / \mathrm{L}$ & 3.45 & 12.58 & 0.973 & 0.69 & 27.55 & 0.996 & 26.74 \\
\hline & $4.0 \mathrm{~g} / \mathrm{L}$ & 3.36 & 9.56 & 0.965 & 0.86 & 20.49 & 0.998 & 19.83 \\
\hline \multirow[t]{4}{*}{ Cadmium } & $0.5 \mathrm{~g} / \mathrm{L}$ & 2.37 & 9.62 & 0.889 & 0.33 & 11.83 & 0.987 & 10.52 \\
\hline & $1.0 \mathrm{~g} / \mathrm{L}$ & 2.28 & 7.63 & 0.905 & 0.40 & 9.51 & 0.990 & 8.47 \\
\hline & $2.0 \mathrm{~g} / \mathrm{L}$ & 1.91 & 5.28 & 0.916 & 0.53 & 7.22 & 0.985 & 6.41 \\
\hline & $4.0 \mathrm{~g} / \mathrm{L}$ & 1.13 & 3.85 & 0.894 & 0.59 & 5.73 & 0.957 & 5.24 \\
\hline
\end{tabular}
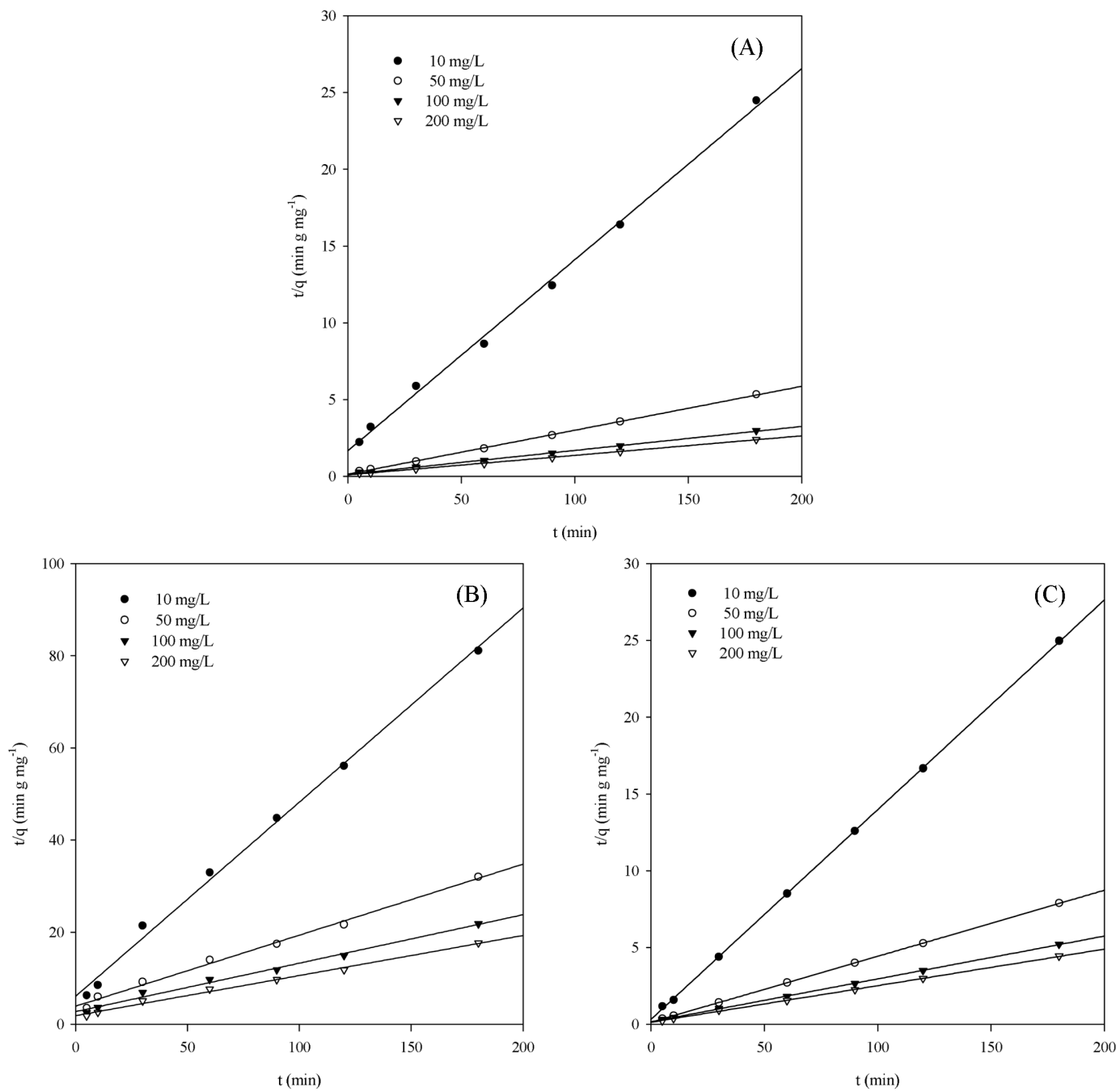

Fig. 12. t/q vs. t plot for the second-order kinetic model for different initial metal concentration. (A): lead, (B): cadmium, (C): copper. 

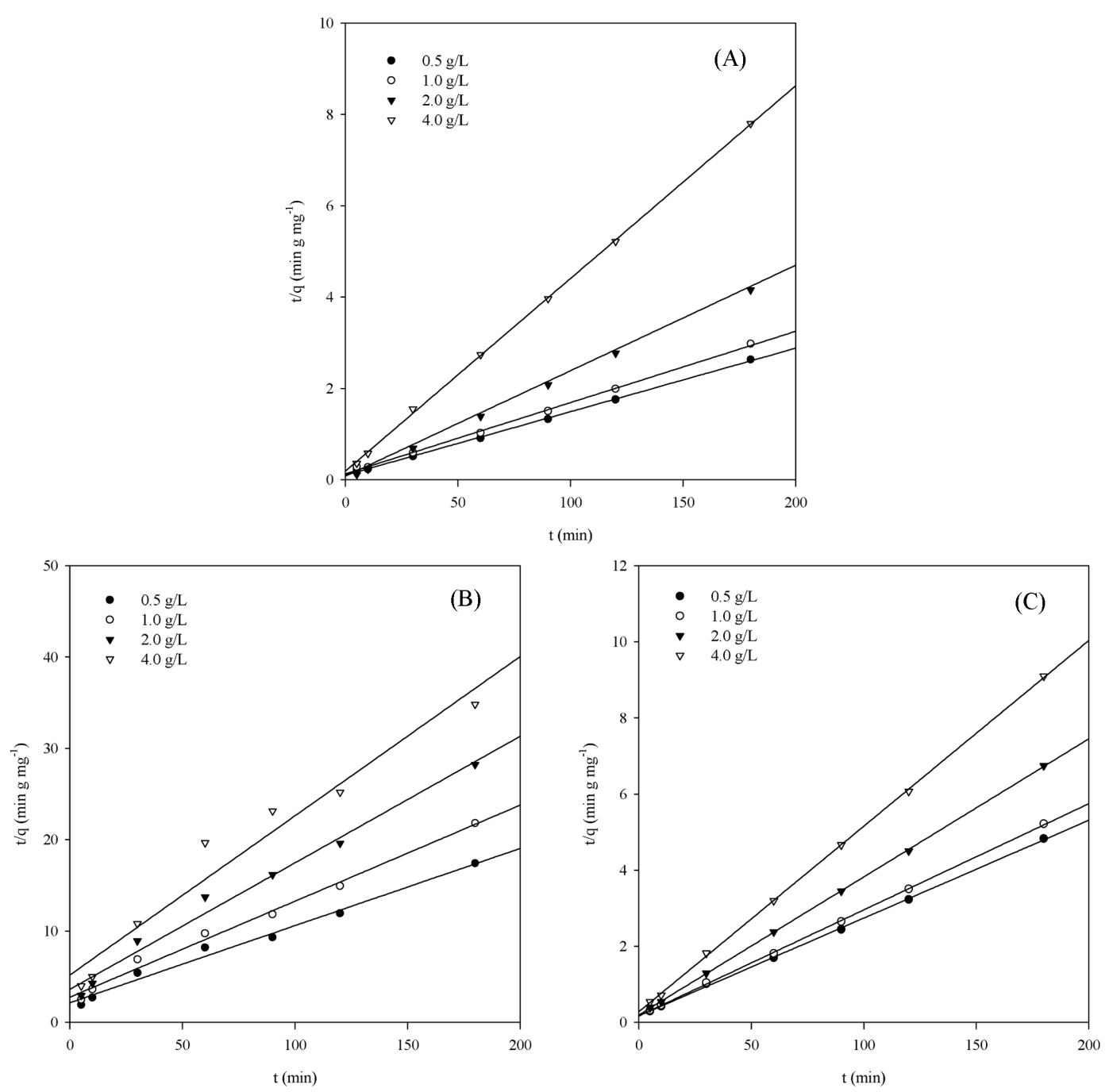

Fig. 13. t/q vs. $t$ plot for the second-order kinetic model for different biosorbent concentration. (A): lead, (B): cadmium, (C): copper.

shown in these tables, the correlation coefficient for the secondorder rate equation is greater than 0.99 and substantially higher than that for the first-order rate equation. And also, the $\mathrm{q}_{e q}$ values calculated from the second order kinetic model agree well with the experimental values. Figs. 12 and 13 show plots of the experimental data and the second-order model for initial metal concentration and biosorbent concentration, respectively. These show that the biosorption of lead, copper and cadmium can be represented by the pseudo second-order reaction.

\section{CONCLUSIONS}

In this study, the biosorption of lead, copper and cadmium was investigated and the following conclusions can be drawn.

1. The uptake capacity of lead, copper and cadmium increased with increasing initial metal concentration and decreased with increasing biosorbent concentration.

2. The uptake capacity increased with increasing $\mathrm{pH}$ and was maximum at $\mathrm{pH} 5.0$ (for $\mathrm{Pb}$ ) and 5.5 (for $\mathrm{Cu}$ and $\mathrm{Cd}$ ). The metal uptake capacities and the effect of $\mathrm{pH}$ were in the order of lead> copper>cadmium, and the maximum metal uptakes were $96.4 \mathrm{mgPb} /$ $\mathrm{g}, 48.9 \mathrm{mgCu} / \mathrm{g}$ and $14.3 \mathrm{mgCd} / \mathrm{g}$, respectively.

3. The biosorption isotherm was well described by Langmuir model of favorable type, and the pseudo second-order kinetic model represented the experimental data very well.

4. The biosorption of the heavy metals was endothermic reaction, and the heats of reaction were $4.06,3.30$ and $5.35 \mathrm{kcal} \cdot \mathrm{mol}^{-1}$ for lead, copper and cadmium, respectively.

\section{ACKNOWLEDGMENT}

This research was financially supported by the Korea Science and Engineering Foundation (R01-2002-00337-0), and Sun-Kyu Park and Seung-Jai Kim acknowledge the support by the Korea Science and Engineering Foundation (No. M02-2003-000-20439-0).

\section{NOMENCLATURE}

$\mathrm{C}_{e}$ : equilibrium adsorbates concentration in the liquid phase [mmol/L]

$\mathrm{K}_{1, \text { ad }}$ : rate constant of first-order biosorption $\left[\mathrm{min}^{-1}\right]$ 
$\mathrm{K}_{2, a d}$ : rate constant of second-order biosorption $\left[\mathrm{g} \mathrm{mg}^{-1} \mathrm{~min}^{-1}\right.$ ]

$\mathrm{q}$ : adsorbative capacity per unit mass of adsorbent [mmol/g]

$\mathrm{q}_{m} \quad$ : Langmuir constant [-]

$\mathrm{q}_{e q}$ : adsorbed amount on the biosorbent at equilibrium [mg/g]

$\mathrm{q}_{t}$ : adsorbed amount on the biosorbent at time $\mathrm{t}[\mathrm{mg} / \mathrm{g}]$

$\mathrm{R}$ : correlation coefficient [-]

$\mathrm{V}$ : volume of liquid [L]

$\Delta \mathrm{H}$ : heat of adsorption $[\mathrm{kcal} / \mathrm{mol}]$

$\mathrm{R}$ : universal gas constant $[\mathrm{cal} / \mathrm{mol} \mathrm{K}]$

$\mathrm{T}$ : absolute temperature $[\mathrm{K}]$

\section{REFERENCES}

Aderhold, D., Williams, C. J. and Edyvean, R. G. J., "The Removal of Heavy Metal Ions by Seaweed and Their Derivatives,' Bioresour. Technol., 58, 1 (1996).

Aksu, Z. and Dönmez, G., "A Comparative Study on the Biosorption Characteristics of Some Yeasts for Remazol Blue Reactive Dye," Chemosphere, 50, 1075 (2003).

Avery, S. V. and Tobin, J. M., "Mechanisms of Strontium Uptake by Laboratory and Brewing Strains of Saccharomyces cerevisiae," Appl. Environ. Microbiol., 58, 3883 (1992).

Avery, S. V. and Tobin, J. M., "Mechanism of Adsorption of Hard and Soft Metal Ions to Saccharomyces cerevisiae and Influence of Hard and Soft Anions,' Appl. Environ. Microbiol., 59, 2851 (1993).

Baliley, S. E., Olin, T. J., Bricka, R. M. and Adrian, D. D., "A Review of Potentially Low-cost Sorbents for Heavy Metals," Water Research, 33, 2469 (1999).

Benguella, B. and Benaissa, H., "Cadmium Removal from Aqueous Solutions by Chitin: Kinetic and Equilibrium Studies,' Water Research, 36, 2463 (2002).

Blanco, A., Sanz, B., Llama, M. J. and Serra, J. L., "Biosorption of Heavy Metals to Immobilised Phormidium laminosum Biomass,' Journal of Biotechnology, 69, 227 (1999).

Eccles, H., "Removal of Heavy Metals from Effluent Streams - Why Select a Biological Process,' International Biodeterioration \& Biodegradation, 35, 5 (1995).

Esposito, A., Pagnanelli, F. and Veglio, F., "pH Related Equilibria Models for Biosorption in Single Metal System,' Chemical Engineering Science, 57, 307 (2002).

Ho, Y. S. and Mckay, G., "Sorption of Dye from Aqueous Solution by Peat,' Chemical Engineering J., 70, 115 (1998).

Jeon, C., Park, J. Y. and Yoo, Y. J., "Removal of Heavy Metals in Plating Wastewater Using Carboxylated Alginic Acid,' Korean J. Chem. Eng., 18, 955 (2001).

Jianlon, W., "Biosorption of Copper(II) by Chemically Modified Biomass of Saccharomyces cerevisiae," Process Biochmistry, 37, 847 (2002).
Kapoor, A. and Viraraghavan, T., "Fungal Biosorption- An Alternative Treatment Option for Heavy Metal Bearing Wastewaters: A Review,' Bioresource Technology, 53, 195 (1995).

Lagergren, S., "zur Theorie der sogenannten adsorption geloster stöffe, Kungliga Sevenska Vetenskapsakademiens,' Handlingar, 24, 1 (1898).

Lee, H. S. and Suh, J. H., "Continuous Biosorption of Heavy Metal Ions by Ca-loaded Laminaria japonica in Fixed Bed Column,' Korean J. Chem. Eng., 17, 477 (2000).

Low, K. S., Lee, C. K. and Liew, S. C., "Sorption of Cadmium and Lead from Aqueous Solutions by Spent Grain,' Process Biochemistry, 36, 59 (2000).

Marques, P. A., Pinheiro, H. M., Teiseira, J. A. and Rosa, M. F., "Removal Efficiency of $\mathrm{Cu}^{2+}, \mathrm{Cd}^{2+}$, and $\mathrm{Pb}^{2+}$ by Waste Brewery Biomass: $\mathrm{pH}$ and Cation Association Effects," Desalination, 124, 137 (1999).

Nakajima, A., Horikoshi, T. and Sakaguchi, T., "Recovery of Uranium by Immobilized Microorganisms,' Eur. J. Appl. Microbiol. Biotechnol., 16, 88 (1982).

Özer, A. and Özer, D., "Comparative Study of the Biosorption Pb(II), $\mathrm{Ni}(\mathrm{II})$ and $\mathrm{Cr}$ (VI) Ions onto $S$. cerevisiae: Determination of Biosorption Heats," Journal of Hazardous Materials B100, 219 (2003).

Sağ, Y. and Kutsal, T., "Recent Trends in the Biosorption of Heavy Metals: A Review,' Biotechnol. Bioprocess Eng., 6, 376 (2001).

Smith, J. M., Chemical Engineering Kinetic, 3rd Edition., McGrawHill, New-York (1981).

Sudha, S. R. and Abraham, T. E., "Biosorption of Cr(VI) from Aqueous Solution by Rhizopus nigrican," Bioresource Technology, 79, 73 (2001).

Veglio, F. and Beolchini, F., "Removal of Metals by Biosorption: A Review,' Hydrometallurgy, 44, 301 (1997).

Volesky, B., "Detoxification of Metal-bearing Effluents: Biosorption for the Next Century,' Hydrometallurgy, 59, 203 (2001).

Volesky, B., "Advances in Biosorption of Metals: Selection of Biomass Type," FEMS Microbiology Reviews, 14, 291 (1994).

Yan, G. and Viraraghavan, T., "Heavy Metal Removal in a Biosorption Column by Immobilized M. rouxii Biomass,' Bioresource Technology, 78, 243 (2001).

Yang, J. and Volesky, B., "Modeling Uranium-proton Ion Exchange in Biosorption,' Environmental Science and Technology, 33, 4079 (1999).

Yesim, S., "Selection of the Best Biosorbent for Removal and Recovery of the Heavy Metal Ions from Wastewater and Mathematical Investigation of the Adsorption in the Different Reactor Systems,' Ph.D. Thesis, Hacettepe University, Ankara, Turkey (1993).

Yu, Q., Kaewsarn, P., Yu, Q. and Kaewsarn, P., "A Model for pH Dependent Equilibrium of Heavy Metal Biosorption,' Korean J. Chem. Eng., 16, 753 (1999). 